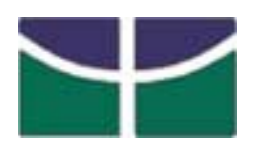

Universidade de Brasília

Centro de Excelência em Turismo

\title{
VALORAÇÃO ECONÔMICA DO ECOTURISMO \\ Estudo de Caso - A Festa do Divino Espírito Santo em Pirenópolis - GO
}

Márlon José Cerqueira

Humberto Angelo

Monografia apresentada ao Centro de Excelência em Turismo da Universidade de Brasília como requisito parcial para a obtenção do certificado de Especialista em Ecoturismo

Brasília, DF, maio de 2003. 
UNIVERSIDADE DE BRASÍLIA

Centro de Excelência em Turismo

Curso de Especialização em Ecoturismo

\section{VALORAÇÃO ECONÔMICA DO ECOTURISMO ESTUDO DE CASO: A FESTA DO DIVINO ESPÍRITO SANTO EM PIRENÓPOLIS - GO}

Márlon José Cerqueira

Humberto Angelo, Dr.

Orientador

Brasília, DF, 26, maio de 2003 
Cerqueira, Márlon José

Valoração Econômica do Ecoturismo. Estudo de Caso: A Festa do Divino Espírito Santo em Pirenópolis - GO / Márlon José Cerqueira.

$\mathrm{x}, 37 \mathrm{f}$.

Monografia (especialização) - Universidade de Brasília.

Centro de Excelência em Turismo. Brasília, 2003.

Área de concentração: Ecoturismo

Orientador: Humberto Angelo

1. Valoração Econômica 2.Ecoturismo 3.Patrimônio Cultural 
Márlon José Cerqueira

\section{VALORAÇÃO ECONÔMICA DO ECOTURISMO \\ ESTUDO DE CASO: A FESTA DO DIVINO ESPÍRITO SANTO EM PIRENÓPOLIS - GO}

Humberto Angelo, Dr.

Brasília, DF, 26, maio de 2003 
“As paisagens urbanas e naturais são multivocais: um mesmo objeto, lugar ou fenômeno tem geralmente vários sentidos e identidades, de acordo com quem os atribui ao longo do tempo. São várias vozes da comunidade, as várias narrativas, tempos e motivos diferentes os econômicos, os estéticos e os políticos. Assim, dar um canal de expressão para que as várias vozes da comunidade interpretem seu patrimônio enriquece a interpretação e a experiência vivencial do visitante, ao mesmo tempo que valoriza o lugar".

MURTA \& GOODEY, 2002. 
A minha amada Rubia pela paciência e ajuda nos momentos difíceis e pela gostosa companhia nas viagens para pesquisa de campo.

Meu especial agradecimento às pessoas que se dispuseram a contribuir com o trabalho, dedicando seu tempo e atenção nas entrevistas da pesquisa, participantes da construção da grandiosa festa do Divino Espírito Santo em Pirenópolis - GO.

A todas as pessoas que acreditaram e ajudaram na realização desse trabalho, em especial ao meu orientador Humberto Angelo. 


\section{RESUMO}

A valoração econômica de bens culturais de natureza imaterial pode, ao mesmo tempo, servir de parâmetro para políticas públicas de investimento e para reparação de danos e necessidades de indenização às comunidades envolvidas com o ecoturismo. A necessidade de proteção do patrimônio cultural se mostra presente à medida que aumenta a ocorrência de impactos ao meio ambiente e às culturas tradicionais provocados pelo turismo. A Festa do Divino Espírito Santo em Pirenópolis serve de base para um estudo inicial do tema por ser a representação maior do folclore daquela comunidade.

Palavras-chave: valoração econômica, ecoturismo, patrimônio cultural. 


\begin{abstract}
The economic valuation of intangible heritage can be of value to both investment in public policies and to the indemnity of the involved localities in the ecotourism in case of prejudice. The need of protection of the intangible heritage is a reality at the present moment as there has been an increase on incidents causing negative impacts by tourism activities to the environment and to the traditional cultures. The "Festa do Divino Espírito Santo" in the city of Pirenópolis serves as the base to an initial study of the issue as it is the major folk representation of this community.
\end{abstract}

Key words: economic valuation, ecotourism, cultural heritage. 


\section{LISTA DE FIGURAS}

Figura 1 - Categorias de valores econômicos atribuídos aos bens ambientais ..............3

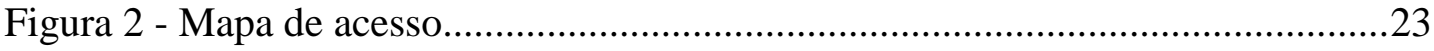




\section{LISTA DE TABELAS}

Tabela 1 - Evolução Populacional........................................................................23 


\section{SUMÁRIO}

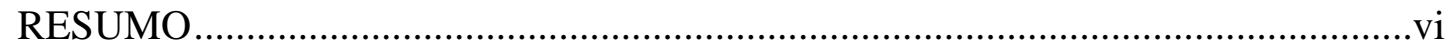

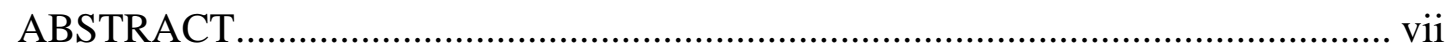

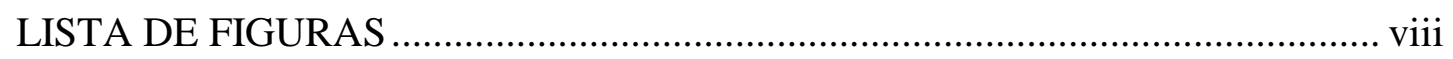

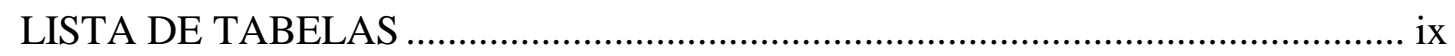

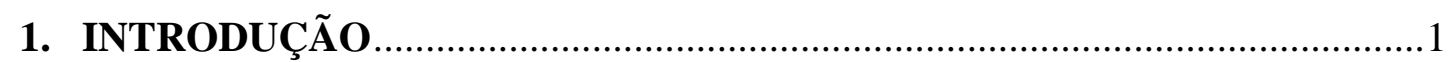

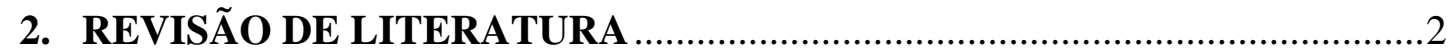

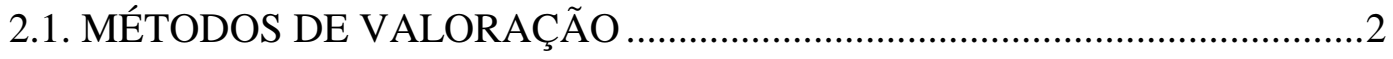

2.1.1. MÉTODO DE PREÇO HEDÔNICO.....................................................

2.1.2. MÉTODO DO CUSTO DE VIAGEM ................................................6

2.1.3. MÉTODO DE VALORAÇÃO CONTINGENTE ....................................8

2.2. VALOR ECONÔMICO DE UM BEM CULTURAL COM BASE NA

VALORAÇÃO DE RECURSOS AMBIENTAIS ……………………..........10

2.3. PATRIMÔNIO CULTURAL COMO RECURSO ECOTURISMO ................11

2.4. VALOR DO PATRIMÔNIO CULTURAL …………......................................13

2.5. PATRIMONIALIZAÇÃO E FOLCLORISMO …………………………........16

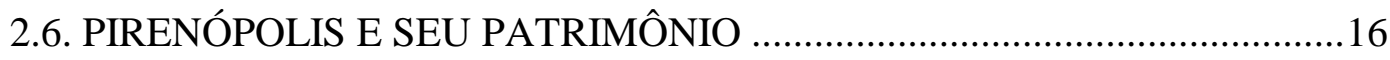

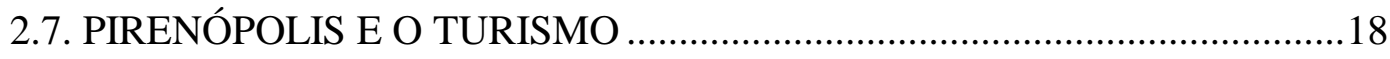

2.8. UM POUCO DA HISTÓRIA DA FESTA DO DIVINO E DAS

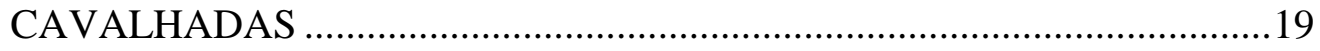

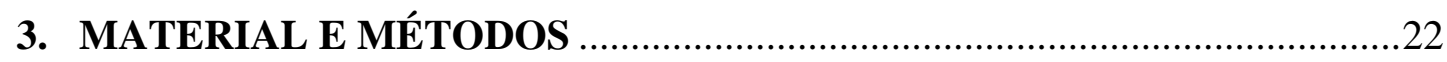

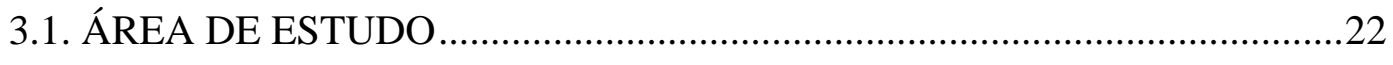

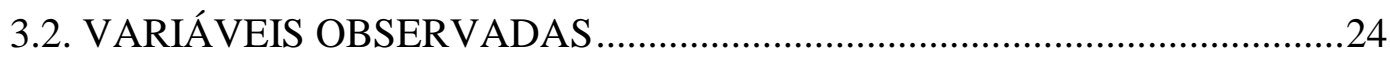

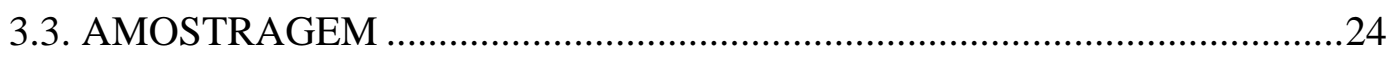

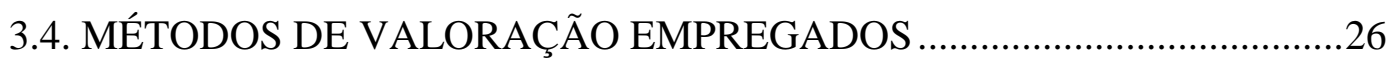

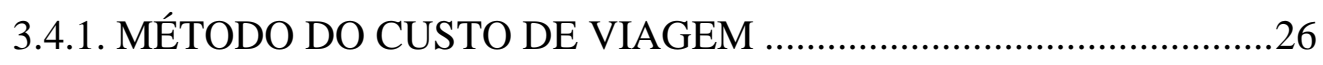

3.4.2. MÉTODO DE VALORAÇÃO CONTINGENTE ..................................26

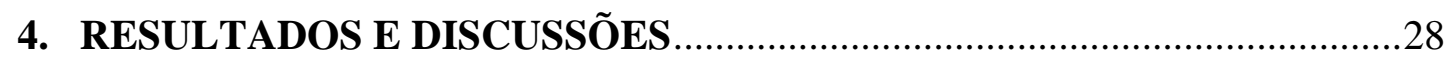

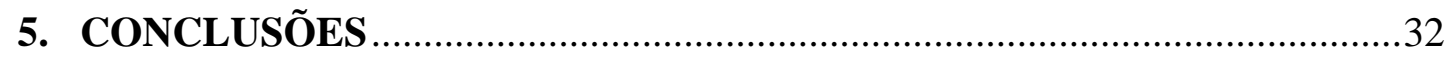

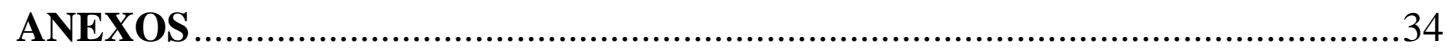

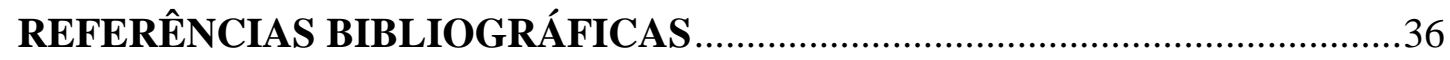




\section{INTRODUÇÃO}

O conceito de Ecoturismo aborda a utilização, de forma sustentável, do patrimônio natural e cultural, incentivando sua conservação e a busca da formação de uma consciência ambientalista pela preservação do ambiente.

Entende-se como patrimônio cultural, os bens de natureza material e imaterial ou intangível. Patrimônio significa herança paterna, bens de família, riqueza ou complexo de bens (FERREIRA, 1993).

Os bens culturais de natureza imaterial são: as formas de expressão, os modos de criar, fazer e viver e as criações científicas, artísticas e tecnológicas, com especial atenção àquelas referentes à cultura popular. Por intermédio deles a humanidade evolui, conhece melhor a si própria e ao universo, e garante sua sobrevivência no seu meio ambiente.

De acordo com o artigo 215 da Constituição Federal "O Estado garantirá a todos o pleno exercício dos direitos culturais e acesso às fontes da cultura nacional, e apoiará e incentivará a valorização e a difusão das manifestações culturais" e no seu Parágrafo $1^{\circ}$. "O Estado protegerá as manifestações das culturas populares, indígenas e afro-brasileiras, e das de outros grupos participantes do processo civilizatório nacional”.

A idéia de desenvolver o presente trabalho surgiu em função da carência de estudos antecedentes no que diz respeito à valoração econômica do patrimônio imaterial brasileiro. Face ao conceito de valoração de bens imateriais estar ligado aos seus valores simbólicos e abstratos, para o Ministério da Cultura, surge como uma nova forma de valorar tais bens, mesmo que de forma empírica, semelhantemente ao que vem acontecendo com os recursos ambientais, de modo a criar uma base de cálculo que sirva de referência para políticas públicas de investimentos e para os casos de danos e necessidades de reparação/indenização às comunidades.

Este trabalho trata da valoração dos bens imateriais de uma cultura. Mais especificamente, a comunidade de Pirenópolis - GO, em sua representação maior do folclore - A Festa do Divino Espírito Santo (incluindo as Cavalhadas) - para servir de base para o estudo proposto. 


\section{REVISÃO DE LITERATURA}

\subsection{MÉTODOS DE VALORAÇÃO}

O valor de um bem é obtido pela sua utilidade, raridade ou escassez ou pela sua qualidade. O valor econômico é um importante aspecto a ser considerado no processo de tomada de decisão e pode ser conceituado como a disposição de alguém a pagar por algo baseado em seus gostos, valores, preferências e de acordo com as vantagens e desvantagens de um bem ou serviço em relação a outros (MOTTA, 1998).

A definição do valor de um bem envolve seus valores de uso direto, indireto e pela sua existência e valor de opção.

O valor de uso direto representa o que os indivíduos consomem no presente, enquanto o indireto representa o benefício atual do recurso derivado de outras funções. $\mathrm{O}$ valor de existência, dissociado do uso, deriva-se de uma posição moral, cultural, ética em relação à existência ou preservação do bem, independente de seu uso presente ou futuro. Já o valor de opção representa o valor que o indivíduo atribui no presente a um determinado recurso, visando ter a opção de uso futuro desse recurso (MOTTA, 1998). 
Figura 1 - Categorias de valores econômicos atribuídos aos bens ambientais.

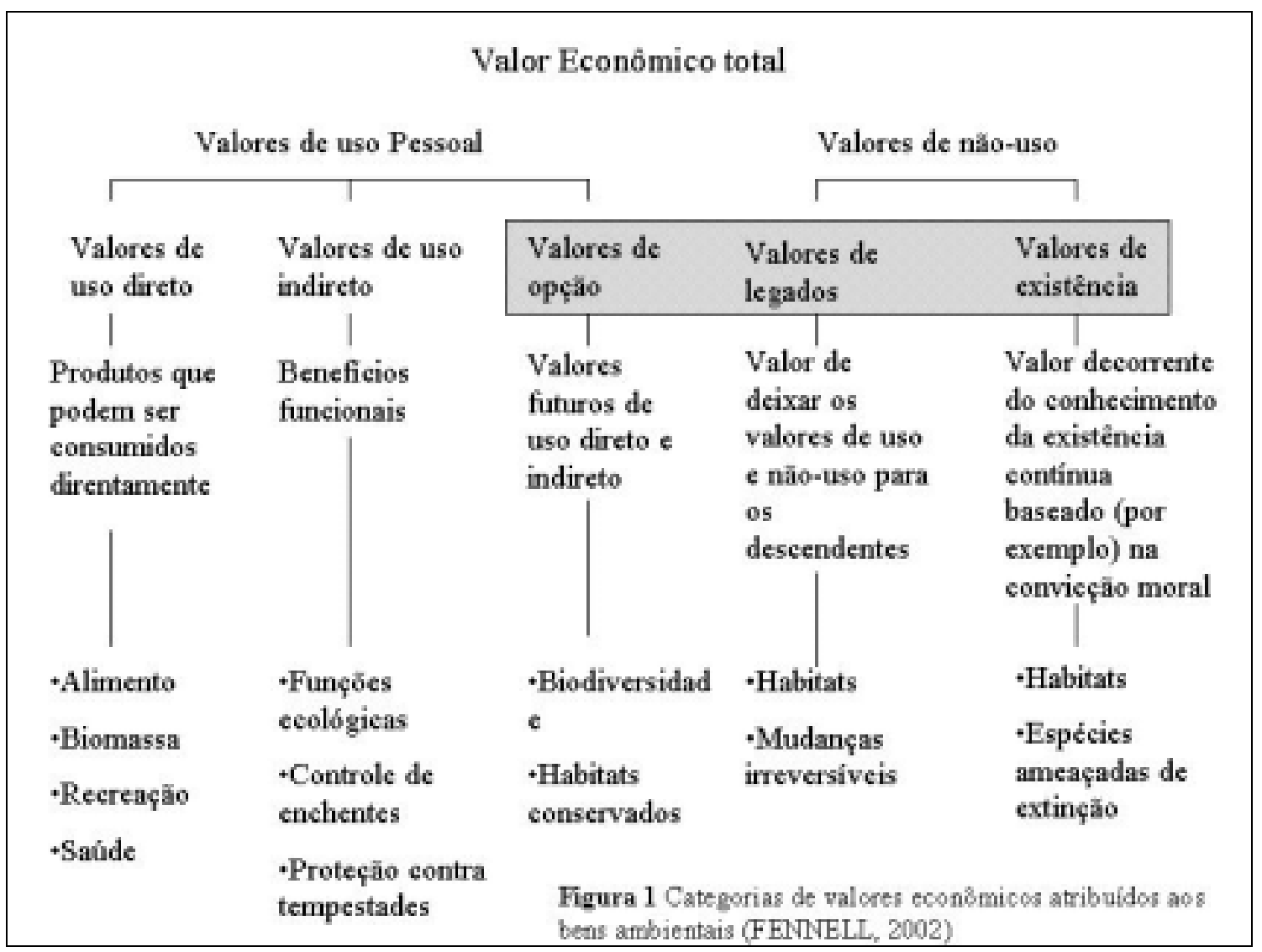

Fonte: FENNELL, 2002

Diversos métodos de valoração econômica foram desenvolvidos e apresentam-se segmentados em:

Método Direto, onde o valor do bem é obtido pelo preço de mercado;

Métodos Indiretos:

- Valor Residual

- Valor Incremento da Produção

- Preços Sucedâneos

- Custo Renovação

- Preços Hedônicos

- Custo de Viagem 
Método de Fixação de Preços de Bens e Serviços Não Comerciais: Método de Valoração Contingente (MVC).

Alguns desses métodos são comumente utilizados na valoração de recursos ambientais, mais especificamente os métodos de função de demanda. Estes métodos estimam diretamente os valores econômicos com base em funções de demanda para estes recursos derivados de mercados de bens ou serviços privados complementares ao recurso ambiental ou mercados hipotéticos construídos especificamente para o recurso ambiental em análise. Utilizando-se de funções de demanda, estes métodos permitem captar as medidas de disposição a pagar (ou aceitar) dos indivíduos relativos às variações de disponibilidade do recurso ambiental. Com base nestas medidas, estimam-se as variações do nível de bem-estar pelo excesso de satisfação que o consumidor obtém quando paga um preço (ou nada paga) pelo recurso abaixo do que estaria disposto a pagar (MOTTA, 1998).

Quando os custos da degradação ecológica não são pagos por aqueles que a geram, estes custos são externalidades para o sistema econômico. Ou seja, custos que afetam terceiros sem a devida compensação. Atividades econômicas são, desse modo, planejadas sem levar em conta essas externalidades ambientais e, conseqüentemente, os padrões de consumo das pessoas são forjados sem nenhuma internalização dos custos ambientais. O resultado é um padrão de apropriação do capital natural onde os benefícios são providos para alguns usuários de recursos ambientais sem que estes compensem os custos incorridos por usuários excluídos. Além disso, as gerações futuras serão deixadas com um estoque de capital natural resultante das decisões das gerações atuais, arcando os custos que estas decisões podem implicar.

Embora o uso de recursos ambientais não tenha seu preço reconhecido no mercado, seu valor econômico existe na medida que seu uso altera o nível de produção e consumo (bem-estar) da sociedade.

A satisfação dos consumidores é ponderada e deriva-se de todas as formas de consumo. Isto é, o bem-estar das pessoas é medido tanto pelo consumo de bens e serviços, como pelo consumo de amenidades de origem recreacional, política, cultural e ambiental. A análise social de custo-benefício visa atribuir um valor social a todos os efeitos de um determinado projeto, investimento ou política. Os efeitos negativos são encarados como custos e os positivos são tratados como benefícios. Como se pretende comparar custos e 
benefícios, surge a necessidade de expressá-los em uma medida comum, ou seja, em um mesmo numerário ou unidade de conta. Por isso, estes custos e benefícios são expressos em termos monetários. Todavia, existem algumas dificuldades neste processo de agregação de todos os efeitos em um único indicador (MOTTA, 1998).

Se estes custos e benefícios refletem os gastos a preços de mercado dos bens e serviços comprados ou vendidos, o processo de identificação e estimação é mais simples e objetivo. Custo e benefício serão, respectivamente, o somatório dos valores monetários dos gastos e receitas Deve-se destacar que alguns bens e serviços a serem valorados não são transacionados em mercado e, portanto, não têm preços definidos.

Isso dificulta a utilização de alguns métodos na valoração ambiental e acaba por direcionar os trabalhos para três deles, quais sejam: o Método de Preços Hedônicos, o Método pelo Custo de Viagem e o Método de Valoração Contingente.

Neste capítulo procuraremos abordar resumidamente esses três métodos como forma de evidenciar vantagens e desvantagens na aplicação de cada um deles.

\subsubsection{Método de Preço Hedônico (MOTTA, 1998)}

O método baseia-se na identificação de atributos ou características de um bem composto privado, cujos atributos são complementares a bens ou serviços ambientais. Uma vez identificada uma relação de complementaridade, pode-se mensurar o preço implícito do atributo ambiental.

A abordagem permite avaliar o preço implícito de um atributo ambiental na formação de um preço observável de um bem composto

De acordo com Motta (1998), o método de avaliação hedônica requer algumas precauções para que seu emprego possa produzir estimativas confiáveis. Dentre outras, cita-se a necessidade de se proceder a um acurado levantamento de dados, envolvendo, além dos indicadores ambientais, informações sobre os diversos atributos ambientais que exercem influência sobre o preço da propriedade, como também características intrínsecas da propriedade, facilidades de serviços, qualidade do local e informações socioeconômicas das propriedades sobre uma amostra representativa das propriedades da região. 
O método do preço de propriedade pode ser uma forma bastante útil para captar medidas de disposição a pagar por valores de uso do meio ambiente. Todavia, estas medidas serão mais acuradas quando mensurarem variações marginais na disponibilidade destes bens. Para estimar variações de bem-estar para variações não marginais, algumas hipóteses sobre o funcionamento do mercado de propriedades terão que ser assumidas.

A necessidade de admitir hipóteses irrealísticas sobre o mercado de propriedades e a exigência de um levantamento sofisticado de informações tem contribuído para que este método do preço de propriedade seja utilizado com bastante precaução. Poucos são os estudos de caso que dele se valeram para valorações de benefícios da biodiversidade.

Além do Método de Preço hedônico, outros dois métodos indiretos utilizados na valoração de ativos ambientais, o Método de Custo de Viagem - MCV e o Método de Valoração Contingente - MVC.

\subsubsection{O Método de Custo de Viagem - MCV (MOTTA, 1998).}

O método utiliza os custos incorridos pelos indivíduos quando viajam a locais de recreação, como substituto do preço do bem ou serviço que é explorado pela referida atividade. Por este método, estima-se que os benefícios gerados por uma determinada atividade ambiental, baseando-se nos custos de utilização das amenidades exploradas pela atividade. Basicamente, o custo de viagem representará, assim, o custo de visitação ao local de destino.

Quanto mais longe do destino os seus visitantes vivem, menos uso deste (menor número de visitas) é esperado que ocorra porque aumenta o custo de viagem para visitação. Aqueles que vivem mais próximos ao local tenderão a usá-lo mais (maior número de visitas), na medida em que o preço implícito de utilizá-lo, o custo de viagem, será menor.

Jurisdições1 são, assim, definidas por distâncias ao destino e, neste sentido, deve ser conhecida a população e outras variáveis sócio-econômicas zonais.

Através de uma pesquisa de questionários realizada no próprio local, é possível levantar estas mesmas informações em uma amostra de visitantes. Assim, cada entrevistado

\footnotetext{
${ }^{1}$ Jurisdições políticas, como por exemplo, países, estados, municípios, etc. podem definir as zonas residenciais.
} 
informa seu número de visitas ao local, o custo de viagem, a zona residencial onde mora e outras informações sócio-econômicas.

O método do custo de viagem, pela suposição de complementaridade, não contempla custos de opção e de existência dado que somente capta os valores de uso direto e indireto associado à visita ao destino.

A maior crítica ao método do custo de viagem diz respeito à própria mensuração deste custo. Dada uma determinada distância, custos para certos meios de transporte são mais baixos do que para outros, mas, podem requerer tempos de viagem maiores. Da mesma forma, o tempo da visita no local também mantém uma relação direta com distância. Assim, é comum na literatura o uso de medidas de custo do tempo somadas aos custos de transporte e outros gastos que reflitam o consumo dos serviços ambientais. A taxa de salário representa um bom indicador para o custo de oportunidade do lazer. Entretanto, distorções no mercado de trabalho sugerem que taxas de salários podem superavaliar o custo do lazer.

Outra restrição à mensuração do custo de viagem refere-se à possibilidade do visitante aproveitar a viagem para visitar outros destinos com finalidades distintas. Detectar tal comportamento na pesquisa de campo é importante e pode permitir ajustes nas estimativas.

O método do custo de viagem, embora teoricamente consistente, apresenta algumas restrições nos seus resultados, que derivam da especificação deficiente do modelo ou das próprias falhas das proposições do método, conforme apontadas adiante.

- $\quad$ Pressupõe-se que a visitação a um local tem um objetivo único, quando na realidade as viagens possuem vários objetivos;

- $\quad$ O Método do Custo de Viagem considera que as pessoas possuem a mesma forma de demanda para um determinado atrativo, não assumindo a nãohomogeneidade dos atributos da população de diferentes zonas;

- A forma de estimar a função para ajustar os dados e a escolha da amostra adequada deve ser feitas com rigor, pois problemas dessa ordem influenciam diretamente no cálculo do excedente do consumidor, podendo superestima-los ou subestima-los; 
- Deve ser observado que as estimativas derivadas do MCV são específicas para o valor de uso direto e indireto de um certo local. Portanto, a transferência de estimativas de uma pesquisa de um certo local para outro não é recomendável;

- As hipóteses assumidas para determinar os custos de viagem, que devem incluir tempo e excluir o consumo de outros serviços não associados ao local, certamente afetam as magnitudes das medidas de variação de bem-estar.

- Dado a suposição de complementaridade, o método não contempla custos de opção e de existência. Somente custos de uso diretos e indiretos, associados ao bem ambiental, são captados pelo MCV.

Apesar dos problemas erguidos na literatura, o método apresenta suas vantagens na valoração de recursos ambientais. Dentre elas destacam-se:

- $\quad$ Observar que, embora esta seja uma cobertura bastante restrita das estimativas do valor econômico, o MCV é um instrumento valioso para definir e justificar ações de investimentos em sítios naturais ou culturais, inclusive para orientar formas de contribuição, tais como, taxas de admissão, serviços de alimentação e outros;

- Cuidar para que a apresentação dos resultados explicite as hipóteses de valoração do custo/tempo de viagem e também as hipóteses utilizadas para mensurar o excedente do consumidor.

\subsubsection{O Método de Valoração Contingente - MVC (MOTTA, 1998).}

Um outro método bastante utilizado para valorar áreas ambientais ou recreativas é o Método de Valoração Contingente, que permite captar, através de entrevistas realizadas com os visitantes no local, os valores pessoais para bens "sem preço" criando para isso um mercado hipotético o que permite captar o valor de uso, o valor de existência e ainda o valor de opção do recurso ambiental à medida que capta a disposição a pagar das pessoas para assegurar um benefício, a disposição a aceitar de abrir mão do benefício, a disposição a pagar (DAP) para evitar uma perda e ainda a disposição a aceitar (DAA) uma perda. 
Neste sentido, busca-se simular cenários, cujas características estejam o mais próximo possível das existentes no mundo real, de modo que as preferências reveladas nas pesquisas reflitam decisões que os agentes tomariam de fato caso existisse um mercado para o bem ambiental descrito no cenário hipotético. As preferências, do ponto de vista da teoria econômica, devem ser expressas em valores monetários. Estes valores são obtidos através das informações adquiridas nas respostas sobre quanto os indivíduos estariam dispostos a pagar para garantir a melhoria de bem estar, ou quanto estariam dispostos a aceitar em compensação para suportar uma perda de bem estar.

A grande vantagem do MVC, em relação a qualquer outro método de valoração, é que ele pode ser aplicado em um espectro de bens ambientais mais amplo. A grande crítica, entretanto, ao MCV é a sua limitação em captar valores que indivíduos não entendem, ou mesmo desconhecem. Enquanto algumas partes do ecossistema podem não ser percebidas como geradoras de valor, elas podem, entretanto, ser condições necessárias para a existência de outras funções que geram usos percebidos pelo indivíduo. Nestes casos, o uso de funções de produção e de danos poderia ser mais apropriado, embora com as limitações já assinaladas. A idéia consiste em valorar os benefícios derivados de melhoria ambiental, em função da disposição pelo pagamento dos beneficiários diretos desta melhoria. Da mesma forma, os custos derivados de um dano ambiental serão valorados por meio da quantidade monetária que as pessoas, que sofrem estes prejuízos, aceitarão como medida de compensação.

Como para a maioria dos recursos ambientais não existe um mercado, o método MVC utiliza-se de questionários, em que se pergunta aos indivíduos, que recebem melhoria ou sofrem dano ambiental, o quanto eles estariam dispostos a pagar ou a aceitar pela melhoria ou dano, respectivamente.

Dentre os vieses estimativos do método, dois são os de maior destaque na literatura:

- Viés Estratégico: consiste na pré-disposição do usuário, beneficiário da melhoria, subestimar os valores de sua verdadeira disposição a pagar. Da mesma sorte, em caso de dano, os indivíduos que sofrem a agressão podem sobreestimar o verdadeiro valor de seus prejuízos, na expectativa de receberem indenizações maiores. 
- Viés do Entrevistador: este viés diz respeito à forma como o entrevistador se comporta no ato da aplicação dos questionários. Se este apresentar o recurso ambiental como algo positivo, relevante para comunidade etc., ou, por outro lado, como algo extremamente negativo, pode induzir os entrevistados à formação de um ponto de vista que pode não representar o verdadeiro desejo dos beneficiários diretos de uma melhoria ambiental de um certo recurso. Portanto, a atitude do entrevistador deve ser de absoluta neutralidade, ou seja, deve-se evitar que prevaleçam suas motivações e convicções pessoais com relação ao problema investigado.

Em todo caso, o MVC tem sido largamente empregado na valoração de ativos ambientais sem mercado, proporcionando estimativas razoáveis, além de permitir, com relativa facilidade, valores monetários de ativos ambientais difíceis de serem valorados.

\subsection{VALOR ECONÔMICO DE UM BEM CULTURAL COM BASE NA VALORAÇÃO DE RECURSOS AMBIENTAIS}

O valor econômico dos recursos ambientais geralmente não é observável no mercado através de preços que reflitam seu custo de oportunidade. $\mathrm{O}$ valor econômico dos recursos ambientais é derivado de todos os seus atributos e segundo o qual esses atributos podem ou não estar associados a um uso. Assim o valor econômico de um recurso ambiental é definido como a soma do valor de uso direto, do valor de seu uso indireto, do valor de opção ou de existência desse produto (MOTTA, 1998).

A base metodológica para estimar o valor de um bem ou serviço ambiental é a matemática financeira. Buscaremos neste estudo, utilizando-se das metodologias em uso para valorar economicamente os recursos ambientais aceitas no meio acadêmico, adequá-las para sua utilização com bens culturais de forma a encontrar a que melhor se aplique na expressão cultural escolhida como base de pesquisa - a Festa do Divino Espírito Santo com seus festejos religiosos e a encenação das Cavalhadas em Pirenópolis-GO.

Tendo como base que a valoração econômica dos bens culturais de natureza imaterial visa a preservação das culturas locais, e que para isso precisa ser entendida e aceita pela comunidade, é de vital importância a redescoberta de valores e tradições. 


\subsection{PATRIMÔNIO CULTURAL COMO RECURSO ECOTURÍSTICO}

No início da década de 1980 Ceballos-Lascuráin definiu ecoturismo como "viajar para áreas naturais relativamente não perturbadas nem contaminadas com o objetivo específico de estudar e admirar o cenário e seus animais e plantas selvagens, assim como quaisquer manifestações culturais (passadas e presentes) encontradas nessas áreas". Acredita-se, porém, que o termo ecoturismo tenha aparecido anteriormente no trabalho de Hetzer, em 1965, que o usou para explicar o relacionamento entre os turistas e o meio ambiente e culturas com as quais eles interagem (FENNELL, 2002:41).

Em agosto de 1994, no Brasil, o Grupo de Trabalho Interministerial em Ecoturismo, que reuniu o Ministério da Indústria, Comércio e Turismo e o Ministério do Meio Ambiente e da Amazônia Legal, além da Embratur, Ibama, empresários e consultores, chegou à seguinte conceituação: "Ecoturismo é um segmento da atividade turística que utiliza, de forma sustentável, o patrimônio natural e cultural, incentiva sua conservação e busca a formação de uma consciência ambientalista através da interpretação do ambiente, promovendo o bem-estar das populações envolvidas" (LINDBERG \& HAWKINS, 2001:17).

Atualmente os termos Ecoturismo, Turismo de Aventura e Turismo Cultural têm sido considerados quase totalmente sinônimos, devido à sobreposição dos três ter-se tornado mais forte. Dependendo do local e da situação as faces se expandem ou contraem para representarem diferentes concentrações de aventura, cultura e ecoturismo (FENNELL, 2002:61).

Ao definir ecoturismo, autores e organizações utilizam-se de variadas formas de se expressar, parecendo ser o maior ou menor grau de atendimento às necessidades sócioculturais das regiões receptoras o maior diferencial entre as diversas definições, mas alguns pontos são comuns em suas considerações como: melhorar as condições sócio-econômicas da população local pelas atividades turísticas e a conscientização do turista e das comunidades locais para assuntos ecológicos e/ou culturais.

Diversos organismos internacionais, como The Ecotourism Society, 1993, Ecotourism Association of Australia - EAA, 1998, Pacific Asia Travel Association - PATA, 1998, demonstrando preocupação com o tema, têm tido iniciativas de estabelecer diretrizes para 
operadoras do ecoturismo, e dentre elas com a preservação dos bens culturais das comunidades envolvidas. Listamos abaixo alguns exemplos desses itens (NIEFER \& SILVA, 1999):

- Preparar os viajantes visando minimizar os seus impactos negativos, tanto em aspectos ambientais quanto culturais;

- $\quad$ Preparar os viajantes para cada encontro com culturas locais, animais e plantas nativas;

- $\quad$ Assegurar que administradores, pessoal e empregados contratados saibam e participem da política das empresas para prevenir impactos no ambiente e cultura local;

- Respeitar as características de outras culturas;

- $\quad$ Empregar guias instruídos, que respeitem os ambientes e culturas locais;

- Fornecer educação, interpretação e diretrizes apropriadas aos clientes, respeitando a história natural e cultural da área visitada;

- Contribuir para a conservação de qualquer habitat de flora ou fauna e de qualquer lugar natural ou cultural que pode ser afetado pelo turismo;

- $\quad$ Assegurar que atitudes da comunidade, valores culturais, incluindo costumes e crenças locais, são considerados no planejamento de projetos turísticos.

Outro exemplo foi a realização em maio de 2002 do encontro ${ }^{2}$, com mais de mil integrantes dos setores público e privado e de organizações não-governamentais oriundos de cerca de 132 países, em Quebec, no Canadá, para discutirem e registrarem uma agenda preliminar e estabelecerem uma série de recomendações para o crescimento das atividades do ecoturismo implementadas sob o contexto do crescimento sustentável. Dentre as sugestões e recomendações apresentadas, destacamos algumas ligadas à preservação da cultura das comunidades envolvidas no processo turístico:

\footnotetext{
${ }^{2}$ Cúpula de Especialistas em Ecoturismo em Quebec, no Canadá - de 19 a 22 de maio de 2002.
} 
- $\quad$ Enfatizam que o ecoturismo deve contribuir para que a indústria do turismo seja mais sustentável elevando os benefícios econômicos para as comunidades anfitriãs, contribuindo ativamente para a conservação dos recursos naturais e integridade cultural das comunidades e conscientizando os turistas a respeito da importância das heranças naturais e humanas;

- $\quad$ Reconhecem a diversidade cultural associada às áreas naturais, especialmente por causa da presença histórica das comunidades locais responsável pela manutenção dos conhecimentos tradicionais, usos e práticas sustentáveis trazidas ao longo dos séculos;

- $\quad$ Reforçam que, quando mal planejada e desenvolvida, a atividade do turismo em áreas naturais e rurais contribui para o aumento da pobreza, deteriorização das paisagens, erosão das culturas tradicionais, redução da qualidade e quantidade de água e constitui uma ameaça para a vida selvagem e biodiversidade;

- Recomendam aos governos que em conjunto com as comunidades locais, setor privado, ONGs e todas as partes interessadas, garantam a proteção da natureza, das culturas locais e especialmente do conhecimento tradicional e dos recursos genéticos;

- $\quad$ Recomendam às comunidades e organizações locais que fortaleçam, estimulem e encorajem a habilidade da comunidade em manter e utilizar conhecimentos tradicionais que sejam relevantes para a atividade do ecoturismo, como o artesanato, a agricultura, o folclore, a culinária e demais atividades que utilizam os recursos locais de forma sustentável.

\subsection{VALOR DO PATRIMÔNIO CULTURAL}

Em 1989 foi aprovada pela Conferência Geral da UNESCO a Recomendação sobre a Salvaguarda da Cultura Tradicional e Popular que é assim definida:

Conjunto de criações que emanam de uma comunidade cultural, fundadas na tradição, expressas por um grupo ou por indivíduos, e que reconhecidamente 
respondem às expectativas da comunidade enquanto expressão de sua identidade cultural e social. Seus padrões e valores são transmitidos oralmente, por imitação ou por outros meios. Suas formas compreendem, entre outras, a língua, a literatura, a música, a dança, os jogos, a mitologia, os ritos, os costumes, o artesanato, a arquitetura e outras artes.

A partir de 1995 a UNESCO e a OMPI - Organização Mundial de Propriedade Intelectual - vêm promovendo encontros e congressos com o propósito de discutir a proteção do patrimônio cultural de natureza imaterial, estando por trás dessas iniciativas a prerrogativa de que esses bens têm, além de valor cultural, valor econômico (SANT’ANNA, 2001).

No Brasil, o reconhecimento do papel das expressões populares (bens imateriais) na formação de nossa identidade cultural remonta aos anos 30 e faz parte do contexto de criação do Instituto do Patrimônio Histórico e Artístico Nacional - IPHAN. Porém, somente na década de 70, embora tendo caráter experimental e não sistemático, é que se buscaram novas reflexões sobre a questão (IPHAN, 2000).

Com a Constituição Federal de 1988, expressou-se o conceito de bens materiais e imateriais e a necessidade de sua preservação, e apoio à valorização e a difusão das manifestações culturais.

Mas foi somente em 1997, num seminário internacional promovido pelo IPHAN, com o objetivo de discutir o resgate e valorização da cultura tradicional e popular, estratégias, instrumentos legais e medidas administrativas como forma de proteção ao patrimônio imaterial e, em especial, a definição de seu conceito, é que se deu realmente o início de ações mais concretas voltadas ao tema.

Como fruto desse seminário foi constituído o Grupo de Trabalho Patrimônio Imaterial - GTPI, que após dezessete meses de estudos elaborou proposta de decreto presidencial, que se materializou no Decreto ${ }^{\circ} 3.551$, de 04 de agosto de 2000, que Institui o Registro de Bens Culturais de Natureza Imaterial do patrimônio cultural brasileiro, através dos livros de Registro dos Saberes; de Registro das Celebrações; de Registro das Formas de Expressão e de Registro de Lugares $^{3}$ e o Programa Nacional do Patrimônio Imaterial foi criado (IPHAN, 2000).

\footnotetext{
${ }^{3}$ Livro de Registro dos Saberes, onde serão inscritos conhecimentos e modos de fazer enraizados no cotidiano das comunidades; II - Livro de Registro das Celebrações, onde serão inscritos rituais e festas que marcam a
} 
A discussão sobre os impactos do turismo no ambiente e nas culturas locais é complexa e ainda inicia-se o desenvolvimento de metodologias e experimentos que analisem todos os seus aspectos. Esses impactos têm ocorrido e de fato, temos muitos casos já clássicos no mercado brasileiro que exemplificam como podem ser desastrosas para a cultura e o meio ambiente as atividades turísticas.

Identifica-se que a comercialização inadequada é um sério problema que envolve esse patrimônio. A produção em série de cópias de objetos tradicionais por "artesãos" inescrupulosos; a introdução de materiais e formas inadequadas em objetos artesanais, com vista ao lucro rápido; e a apropriação gratuita de padrões originais ou princípios tecnológicos tradicionais por indústrias, demonstram a seriedade do problema, ao tempo que destrói, sem nenhuma punição, o patrimônio cultural.

A globalização apresenta dualidade em sua relação com as culturas locais, pois da mesma forma que pode ser implacavelmente predatória quando confronta padrões culturais globalizados e padrões comunitários locais concorrendo e às vezes conflitando abertamente, através do intensivo uso dos meios de comunicação de massa, mudando hábitos e o cotidiano das pessoas sob a figura da modernização, pode ser somatória quando as necessidades e hábitos globalizados são compatíveis com os costumes locais e estes se beneficiam economicamente desse cenário (FALCÃO, 2001).

Diante desse contexto, faz-se necessário um sistema de proteção ao patrimônio imaterial desenhado nestes tempos de globalização que leve em conta a dimensão econômica de nosso patrimônio, e que tenha o apoio da mídia, dos meios de comunicação de massa e de estratégia econômica, formulada pelo governo e pela sociedade (FALCÃO, 2001).

A valoração dos bens de natureza imaterial assume importante papel na formulação dessas estratégicas. Como forma de expressar economicamente possíveis impactos/danos ao patrimônio cultural surge como proposta a valoração econômica dos bens culturais de natureza imaterial, através da aplicação de métodos semelhantemente usados na valoração de recursos naturais.

vivência coletiva do trabalho, da religiosidade, do entretenimento e de outras inscritas manifestações literárias, musicais, plásticas, cênicas e lúdicas; IV - Livro de Registro dos Lugares, onde serão inscritos mercados, feiras, santuários, praças e demais espaços onde se concentram e reproduzem práticas culturais coletivas. 
Conforme cita FALCÃO (2001) o patrimônio cultural que o Brasil preservou, desde 1936 foi basicamente bens materiais como igrejas, palácios, praças, monumentos, dentre outros, deixando de lado bens coletivos, imateriais e não monetarizáveis.

Diferentemente dos bens materiais, a preservação e conservação desses bens não significam mantê-los congelados de forma alguma, mas conhecê-los, documentá-los, registrálos, acompanhar suas transformações, divulgá-los e apoiá-los. Em outras palavras, precisa-se interpretar e comunicar com criatividade para desenvolver na comunidade afeição pela cultura local e trazer a preservação no coração e mente das pessoas (SANT'ANNA, 2001).

\subsection{PATRIMONIALIZAÇÃO E FOLCLORISMO}

A partir das primeiras décadas do século $\mathrm{XX}$, as festas e todo um conjunto de manifestações populares passaram a ser considerados partes integrantes da identidade brasileira, por estarem presentes nelas elementos das culturas portuguesas, indígena e negra. Se durante o século XIX as festas foram vistas pelos intelectuais, imbuídos de idéias cientificistas e deterministas, sob o prisma de uma miscigenação negativa, o início do século XX trouxe novidades, principalmente a partir do movimento modernista, nos anos 20, que mudou o enfoque sobre as manifestações populares (SILVA, 2001:129).

Dois processos têm que ser considerados nesse contexto: a patrimonialização, que em resumo busca proteger o patrimônio cultural, e que com a criação do Instituto do Patrimônio Histórico e Artístico Nacional - IPHAN, teve uma nova dinâmica na questão cultural no Brasil e o folclorismo, movimento iniciado na Europa no século XIX, que busca valorizar as diversas manifestações populares, tomaram caminhos diferentes, porém acabam por se encontrar em certos momentos da história recente (SILVA, 2001:130).

\subsection{PIRENÓPOLIS E SEU PATRIMÔNIO}

Pirenópolis teve seu processo de patrimonialização iniciado na década de 1940 com o tombamento da igreja matriz que recebeu o título de monumento nacional certamente por ser o mais antigo templo católico do estado de Goiás, construído no período aurífero, no século 
XVIII. Esse processo durou até a década de 1980 quando todo o centro histórico foi tombado pelo IPHAN.

Os bens culturais de natureza material têm também sua face imaterial. $\mathrm{O}$ uso e a prática social do espaço vincula a ele valores coletivos que passam a compor a face do bem cultural ligada à coletividade e que se há interesse em guarda-los para a posteridade, só podem ser registrados, pois são processos dinâmicos que se atualizam e se transformam permanentemente (SANT'ANNA, 2001).

No caso das Cavalhadas, até 1958 eram realizadas no largo da Igreja, o que representava o poder da mesma sobre a festa. Sua mudança para o campo de futebol após esse ano representou um enfraquecimento da Igreja, reforçado pela redefinição dos espaços públicos, privados, sagrados e profanos no novo perfil urbano de Pirenópolis, fortalecendo a festividade como manifestação turística e folclórica. A Cavalhada tornou-se um dos símbolos da festa do Divino em Pirenópolis. Ela demonstra como as tradições podem ser modificadas e ao mesmo tempo continuar dando sentido para o grupo envolvido, que faz adaptações, nas quais se conservam os velhos costumes em condições novas ou se usam velhos modelos para novos fins (SILVA, 2001: 163 e 214).

A festa do Divino é, atualmente, uma grande festa da comunidade. Embora tenha assumido outras características, a partir dos anos 70 e 80 , que fizeram a sociedade local redefinir algumas práticas no sentido de acompanhar as mudanças vivenciadas, isto representou a reelaboração de sentidos para a sociedade e não, como acreditam os folcloristas, a destruição de tais práticas. É de crer-se que o grande número de pessoas que passou a visitar a cidade, a partir do período citado, bem como a influência da Goiastur e da política de patrimonialização, influenciaram a mudança de vários eventos, que se tornaram mais elaborados, tanto nas formas de apresentação como na indumentária. Por outro lado, é preciso considerar que essa nova dinâmica da festa aconteceu em função não apenas de grupos externos, mas também de interesses locais em tornar a festa um evento do qual a maior parte das pessoas de Pirenópolis pudesse participar (SILVA, 2001:204).

Além da festa do Divino, a cidade tem um vasto calendário festivo-religioso (AGETUR, 2003):

JANEIRO - Festa de São Sebastião - festa na cidade com leilões, procissões e etc; 
MAIO/JUNHO - Festa do Divino Espírito Santo, Cavalhadas, Mascarados, Procissões, Folias, Teatro, Congada, Congo, Contra-dança, chá, Catira, Reinados e Pastorinhas. - Festa móvel, 50 dias após o Domingo de Páscoa;

JUNHO/JULHO - Festa do Divino Pai Eterno - Povoado de Lagolândia - 40 km., Festa da Capela - Romaria em louvor à Nossa Senhora Santana - 37 km., Festa do Morro - na lua cheia, Serra dos Pireneus - 25 km;

SETEMBRO - Festa de Nosso Senhor do Bonfim na cidade, Exposição Agropecuária - na cidade e o Canto da Primavera;

OUTUBRO - Aniversário da Cidade - dia 07, Festa de São Judas Tadeu - na cidade.

\subsection{PIRENÓPOLIS E O TURISMO}

Pirenópolis surgiu como uma cidade de grande potencial turístico no cenário nacional sem qualquer planejamento para isso. Repetindo dramaticamente todos os impactos sofridos pelo turismo predatório feito em todo país, tenta hoje resistir a um mal maior que seria a sua desfiguração enquanto cultura e tradição pela ação da especulação imobiliária ocasionada pela compra de imóveis coloniais por populações forasteiras a preços irresistíveis para moradores locais.

O turismo ainda que bem planejado, mas calcado sobre uma cidade com infra-estrutura básica precária acaba por ser minado aqui e ali em sua capacidade de satisfazer os turistas e os próprios agentes receptores.

Não basta enxergar a cidade com um olhar cosmético. Por traz da beleza e limpeza das ruas se escondem os fantasmas das restaurações mal feitas e tecnicamente discutíveis, o medo das tradições ruírem por falta de apoio cultural e a ameaça da natureza circundante sofrer uma depredação pela ação turística, que não enxergou no esoterismo uma resposta para um lazer em áreas naturais.

Encarar esse problema é contribuir para que esta cidade goiana não tenha o mesmo fim que outras cidades históricas brasileiras que vem literalmente ruindo através dos anos pela ação de um turismo feito simplesmente ao sabor do lucro. 


\subsection{UM POUCO DA HISTÓRIA DA FESTA DO DIVINO E DAS CAVALHADAS}

O costume de se homenagear o Divino Espírito Santo é do tempo do Brasil Colônia, sendo encontrado em várias cidades do Brasil, principalmente naquelas onde a mineração, somada com a utilização de índios e escravos se fizeram presente. A história dos festejos esteve sempre ligada, na memória coletiva local, ao poder aquisitivo do Imperador ${ }^{4}$. Possivelmente as Cavalhadas foram sistematizadas por iniciativas dos grupos hegemônicos locais como forma de reafirmar o poder e de legitimar posições sociais (SILVA, 2001: 50).

A festa do Divino Espírito Santo é uma manifestação da religiosidade católica popularizada a partir da Idade Média. Celebrada cinqüenta dias após a Páscoa comemora a descida do Espírito Santo sobre os apóstolos. Em Goiás, as festas foram se difundindo a medida que a Igreja ia ocupando espaço nos arraiais emergentes em função das descobertas auríferas, a partir do século XVIII (SILVA, 2001:21).

O símbolo da Festa do Divino e a mandala de fogo com a pomba branca ao centro. A pomba significa o próprio Divino Espírito Santo e a mandala de fogo o momento que o Espírito Santo desceu sobre os apóstolos, a Pentecostes.

Em Pirenópolis teve seu início em 1819 e as Cavalhadas em 1826. Diferentemente da Festa do Divino Espírito Santo, as Cavalhadas tiveram várias interrupções em suas apresentações, por motivos variados. Somente a partir da década de 1960 é que se estruturou como evento recorrente e representativo da festa do Divino (SILVA, 2001: 162).

A Festa do Divino Espírito Santo de Pirenópolis reúne várias manifestações em uma mesma festa, como é o caso das procissões, do levantamento de mastros, dos fogos, das novenas e dos teatros, as folias, os reinados e juizados, as pastorinhas e as cavalhadas (SILVA, 2001:32).

Autos, danças, e formas diversas de expressão religiosa dão magnitude aos festejos do Divino, registrados desde 1819 na cidade de Pirenópolis. Toda a sociedade se empenha na realização dessas celebrações, considerada seu maior bem cultural e religioso. Destacam-se

\footnotetext{
${ }^{4}$ SILVA, Mônica, A Festa do Divino-Romanização, Patrimônio \& Tradição em Pirenópolis (1890-1988) - Com base na observação da relação dos imperadores do Divino, no século XIX, verifica-se que as pessoas de destaque social e de prestígio econômico prevaleceram como imperadores.
} 
três grandes fases, que constituem e sintetizam o processo ritual: as folias, o império e as cavalhadas. Em torno dessas fases, forma-se uma complexa trama de ritos (VEIGA, 2002:17).

As folias, que remontam do século XIX e cuja versão mais consistente de sua origem está na iniciativa da própria Igreja como uma forma de levar as cerimônias religiosas até os moradores de fazendas, sítios e chácaras, percorre, em seu giro, abençoando os caminhos por onde passa, porém sem nunca repetir, percorrendo serras, vales, matas, cerrados, atravessa córregos e rios, cruzando uma extensa área nos arredores do município. Atualmente (há cerca de 40 anos) a folia também ganhou a área urbana do município à procura de donativos para a Festa. As folias se iniciam suas semanas antes do domingo do Divino e terminam com a entrega na chegada ou remate da folia que acontece no domingo que antecede o domingo do Divino (VEIGA, 2002).

A figura mais importante da festa é a do Imperador, a quem cabe a responsabilidade de promover e cuidar para que tudo se realize com ordem, incentivando, angariando fundos e mobilizando a população nos afazeres da festa.

Sorteado a cada ano, um cidadão pirenopolino, independente de idade ou classe social, assume o comando da festa, tendo como principais atributos são a prodigalidade, a generosidade, a hospitalidade e a distinção, encarnando a própria sociedade e organizando sua festa maior (VEIGA, 2002:18).

O grande dia da Festa na cidade é o domingo do Divino, dia em que é iniciada a encenação das Cavalhadas. Historicamente, nas festas, as cavalhadas fundiam-se com a religiosidade popular católica e, a partir dessa relação, trocaram símbolos que se tornaram elementos culturais locais (SILVA, 2001:49).

As Cavalhadas de Pirenópolis, considerada uma das mais expressivas do Brasil, é um ritual de três dias, cujos preparativos começam uma semana antes no início da Festa do Divino que é marcada pela saída da Folia.

Instituídas pelo Imperador Padre Manoel Amâncio da Luz, em 1826, evocam batalhas medievais em sua complexa encenação eqüestre, autêntico quadro vivo do ciclo carolíngio. De um lado, vestindo azul, o rei cristão: Carlos Magno e os doze pares da França; do outro, o rei 
mouro, o Sultão da Mauritânia, com seu "exército de infiéis" trajando vermelho (VEIGA, 2002:20).

Após as embaixadas, com suas trocas de injúrias e tentativas de conversão mútua, os adversários em campanha iniciam as batalhas, munidos de lanças, pistolas e espadas. Após uma noite de trégua, os combates cessam na tarde do segundo dia, com a vitória da fé cristã, a conversão e o batismo dos mouros. No terceiro e último episódio dessa festa, os dois castelos confraternizam-se sob a paz do Espírito Santo: mouros e cristãos, agora sob a mesma crença religiosa, passam a correr unidos, trocam flores e disputam jogos de tira-cabeças e argolinhas. Em Pirenópolis, os 24 cavaleiros formam um grupo de notáveis que se destacam pela destreza e pelo papel ritual relevante. O poder simbólico de sua assembléia, entretanto, transborda do ritual, definindo muitas vezes, além da política da festa, a da própria cidade (VEIGA, 2002:20).

Dando um toque alegre e brincalhão a festa, os mascarados participam nos intervalos das Cavalhadas e também pelas ruas da cidade, e por trás dos seus disfarces promovem críticas a autoridades e acabam por se tornarem, juntamente com o espetáculo das Cavalhadas, os grandes chamarizes da mídia e do turismo para a festa do Divino de Pirenópolis.

Apesar de por quatro finais de semana consecutivos haver um maior número de pessoas na cidade para assistir aos diversos festejos dessa complexa festa, o grande momento que a cidade se abre para o mundo é o fim de semana em que ocorre o ritual do império e se iniciam as Cavalhadas, que apesar de ter a duração de três dias (domingo, segunda e terça), na segunda e na terça a cidade se esvazia, transformando a Festa numa comemoração doméstica, já que esses dias são feriados municipais e os turistas retornam aos seus compromissos em suas cidades de origem. 


\section{MATERIAL E MÉTODOS}

\section{1 ÁREA DE ESTUDO}

O local de estudo foi o município de Pirenópolis. Fundado como um pequeno arraial em 1727 por uma bandeira chefiada por Manoel Rodrigues Tomar, em decorrência da grande quantidade de ouro ali existente, teve como nome Minas de Nossa Senhora do Rosário. Devido a uma enchente que arrastou metade da ponte construída sobre o Rio das Almas, passou a se chamar Minas de Nossa Senhora do Rosário de Meia Ponte. Foi considerada até fins do século XIX a mais importante cidade do estado de Goiás, e devido à crise na extração do ouro, viveu um período de estabilidade e isolamento que a manteve com suas características mesmo com as grandes transformações ocorridas durante o século $\mathrm{XX}$ (AGETUR, 2003).

O fato de ter-se mantido isolada dos acontecimentos, ao contrário de criar uma cidade fantasma, criou uma cidade viva que manteve acesa a criatividade que sempre a caracterizou, com um forte apego a seus valores, tradições e manifestações culturais (AGETUR, 2003).

Hoje com o nome de Pirenópolis, devido a proximidade à serra dos Pireneus, a cidade tombada pelo Instituto do Patrimônio Histórico e Artístico Nacional possui um dos acervos mais ricos do centro oeste brasileiro (AGETUR, 2003).

Distante 150 Km de Brasília, 120 Km de Goiânia e 67 Km de Anápolis e ligada a essas cidades por estradas asfaltadas, Pirenópolis conta com boa infra-estrutura hoteleira com cerca de 70 estabelecimentos e de alimentação, além de diversas lojas de artesanato.

A cidade possui cerca de 22 mil habitantes entre o município sede e os 10 povoados administrados pela prefeitura municipal, que são: Jaranópolis, Radiolândia, Índio, Caxambu, Capela do Rio do Peixe, Placa, Lagolândia, Goianópolis, Santo Antônio e Bom Jesus, que tem como atividade básica a agropecuária (IBGE, 2003). 
Tabela 1 - Evolução Populacional

\begin{tabular}{|r|r|r|r|}
\hline \multicolumn{5}{|c|}{ População } \\
\hline Ano & População & Urbana & \multicolumn{1}{c|}{ Rural } \\
\hline 1991 & $25056 \mathrm{hab}$ & $9277 \mathrm{hab}$ & $15779 \mathrm{hab}$ \\
\hline 1996 & $24717 \mathrm{hab}$ & $11154 \mathrm{hab}$ & $13563 \mathrm{hab}$ \\
\hline 2000 & $21245 \mathrm{hab}$ & $12475 \mathrm{hab}$ & $8770 \mathrm{hab}$ \\
\hline 2001 & $21216 \mathrm{hab}$ & & \\
\hline
\end{tabular}

Fonte: IBGE, 2003

Em seus arredores existem várias cachoeiras e santuários de vida silvestre. Natureza e cultura são parceiros. O rico patrimônio histórico da cidade, com seus monumentos e casarões antigos, o folclore, as tradições populares, sua típica culinária e o variado artesanato local, alia-se a belíssima paisagem do cerrado, com suas serras e rios, sua fauna e sua flora.

Figura 2 - Mapa de acesso

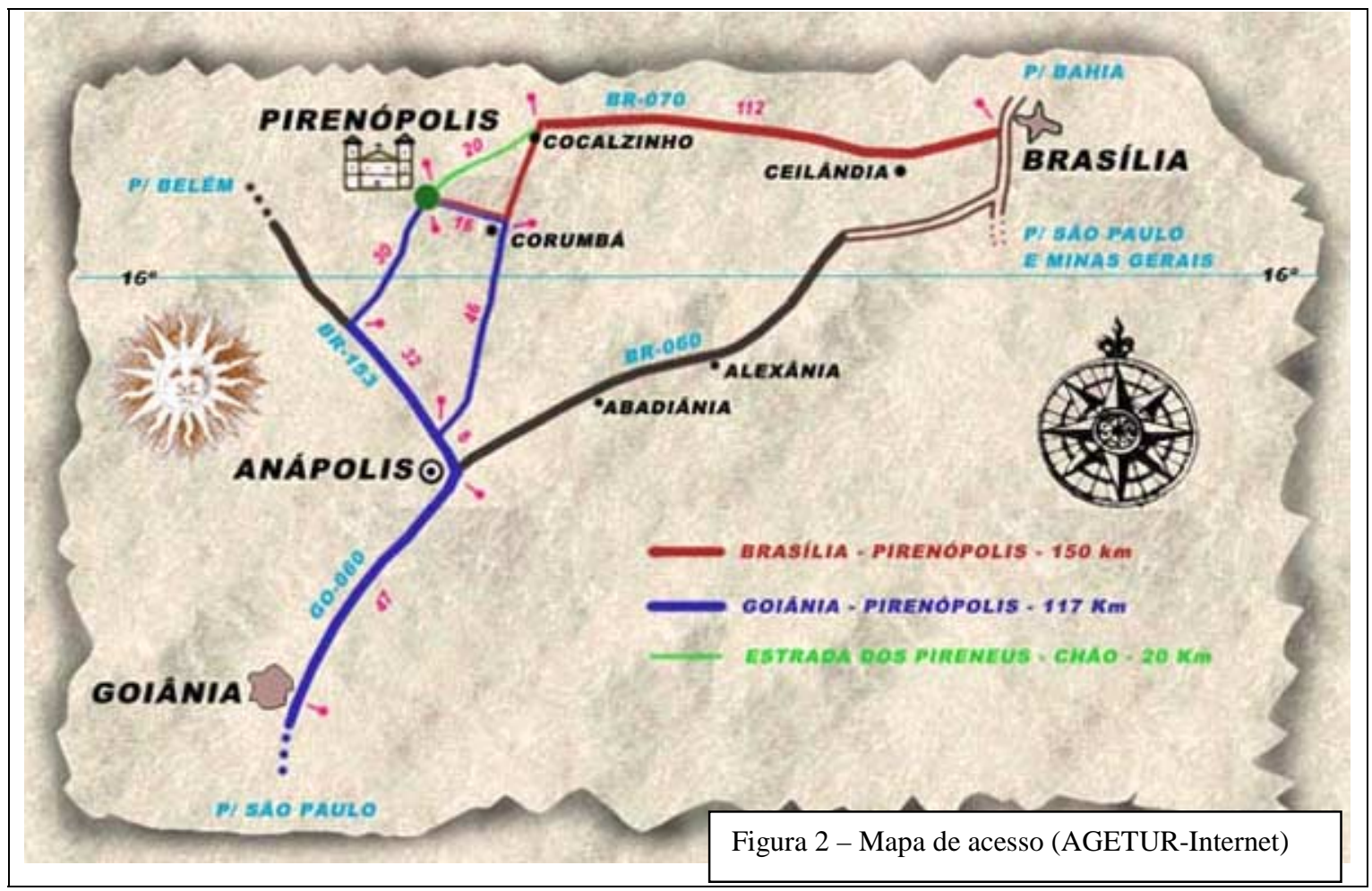

Fonte: AGETUR, 2003 


\subsection{VARIÁVEIS OBSERVADAS}

As principais variáveis da pesquisa de campo foram:

X1 = População Flutuante do município - o valor da variável foi obtido com base na população durante o ponto alto da festa do Divino, ou seja, o fim de semana das Cavalhadas;

X2 = População Economicamente Ativa do município - o valor da variável foi obtido com base em dados do Instituto Brasileiro de Geografia e Estatística - IBGE;

$\mathrm{X} 3$ = Valor Individual gasto por dia da festa - valor obtido levando-se em consideração o somatório dos gastos individuais com viagem, hospedagem, alimentação, bebidas, compras e demais gastos;

X4 = Valor da Disposição a Pagar - DAP - pelo ingresso às Cavalhadas - valor obtido com base na DAP, por ingresso no campo das Cavalhadas na hipótese de cobrança pela entrada;

X5 = Valor da Disposição a Pagar - DAP - de taxa para manutenção da festa - valor obtido com base na DAP, para manutenção da festa no caso de não haver investimentos públicos ou patrocínios privados para sua realização;

X6 = Público que assiste às Cavalhadas - valor da variável obtido considerando a quantidade de pessoas que assistem às Cavalhadas durante o fim de semana.

A utilização dessas variáveis de forma combinada e de acordo com os métodos escolhidos para a pesquisa, permitirão a obtenção dos valores econômicos da Festa do Divino Espírito Santo de Pirenópolis.

\subsection{AMOSTRAGEM}

Como forma de identificar a importância da Festa do Divino Espírito Santo para os moradores de Pirenópolis, foi aplicado um questionário em uma amostra não probabilística da população, que por não fazer uso de formas aleatórias de seleção, torna impossível a aplicação de fórmulas estatísticas para o cálculo da amostra. Tal escolha teve como base a impossibilidade de aplicação do questionário no período da Festa, o reduzido tempo e recursos para a pesquisa de campo.

Sabe-se da superioridade da técnica da amostragem probabilística, onde todos os elementos da população têm a mesma probabilidade de fazer parte da amostra, entretanto, em 
alguns casos, é necessário utilizar a amostra não-probabilística, que é qualquer método em que a possibilidade de escolher um certo elemento do universo é desconhecida (MARCONI \& LAKATOS, 1982).

Neste estudo buscou-se a utilização de amostragem não-probabilística e a escolha da amostra a ser utilizada como base da pesquisa pautou-se na técnica denominada "Julgamento ou Intencional", que tem como suposição básica que se feito um bom julgamento e utilizada a estratégia adequada, podem ser escolhidos os casos a serem incluídos e, assim, chegar a amostras que sejam satisfatórias à pesquisa. Essa técnica é utilizada principalmente quando se deseja obter informações detalhadas sobre questões particulares através da seleção subjetiva de unidades de população. Este tipo de amostragem pode ser usado para populações onde o pesquisador pode ver todas as unidades de população e seleciona aquelas que lhe parecem serem as representativas das condições médias. A população alvo tem de estar perfeitamente definida, homogênea e completamente acessível.

Buscou-se obter uma amostra que, apesar de não representativa da população, possa, através de elementos que pela função desempenhada, cargo ocupado, prestígio social, exercer funções de líderes de opinião na comunidade, e com atos ou atuações ter a propriedade de influenciar a opinião dos demais. Apesar das limitações da técnica utilizada, a mesma tem sua validade dentro do contexto específico do estudo proposto. Como desvantagens, observa-se que os desvios das estimativas não podem ser controlados e também requer considerável conhecimento da população e do grupo selecionado como amostra, possibilitando generalizações arriscadas.

Aplicou-se um reduzido número de questionários, tendo seu direcionamento recaído em proprietários de comércios variados (hotéis/pousadas, restaurantes, bares, lanchonetes, lojas de artesanato, farmácias, dentre outros), pessoas representativas na cidade com relação à Festa, autoridades locais (secretário de turismo e cultura, assessor da Secretaria de turismo e cultura e presidente da associação de empreendimentos turísticos) e moradores tradicionais, em função de servirem de juízes no que diz respeito aos aspectos ligados à Festa do Divino Espírito Santo de Pirenópolis.

O questionário utilizado na pesquisa compunha-se de 18 perguntas, divididas em 03 blocos, o primeiro relacionado ao conhecimento e representatividade da Festa, o segundo 
relacionado às mudanças provocadas no turismo pela Festa e o terceiro e último relacionado aos aspectos financeiros diretos e indiretos gerados pela Festa. Dentre as questões elaboradas haviam itens para respostas abertas e itens para respostas semi-abertas, onde foram dadas opções para nortearem os entrevistados. Do segundo bloco de perguntas relacionadas às mudanças provocadas no turismo pela Festa, composto inicialmente de quatro itens, decidiuse descartar dois deles pelo fato de suas respostas não contribuírem para a conclusão da pesquisa, devido terem sido mal formuladas (a não aplicação de teste piloto, devido ao curto período da pesquisa de campo fez com que tal falha não se evidenciasse).

A aplicação se deu em uma amostra de 28 pessoas escolhidas por indicação de profissionais ligados ao turismo no município.

\subsection{MÉTODOS DE VALORAÇÃO EMPREGADOS}

\subsubsection{MÉTODO DO CUSTO DE VIAGEM}

Com base na pesquisa realizada, considerando os dados obtidos com relação à população flutuante (X1) no principal fim de semana da Festa do Divino Espírito Santo, no qual são realizadas as diversas apresentações folclóricas, incluindo as Cavalhadas, e o valor gasto por pessoa (X3) durante esse período, com relação a despesas com viagem, hospedagem, alimentação, bebidas, compras e demais gastos, podemos chegar a fórmula abaixo:

\section{$\mathrm{VEF}(1)=\overline{\mathrm{X} 1} \times \overline{\mathrm{X} 3}$}

Onde:

VEF(1) = Valor Econômico da Festa pelo MCV

$\overline{\mathrm{X} 1}=$ Média da População flutuante no fim de semana

$\overline{\mathrm{X} 3}=$ Média do Valor gasto por pessoa no fim de semana

\subsubsection{MÉTODO DE VALORAÇÃO CONTINGENTE}

No questionário aplicado, foram apresentadas, aos pesquisados, duas situações hipotéticas com relação à Festa do Divino Espírito Santo. A primeira considerava a 
Disposição a Pagar - DAP - por ingresso para assistir às Cavalhadas (X4); a segunda considerava um cenário de ausência de investimentos públicos e patrocínios privados para realização da Festa e questionava os pesquisados sobre quanto estariam dispostos a pagar (X5) para manterem essa tradição.

Com base nos valores médios obtidos nas respostas à primeira das duas perguntas, e considerando, para aplicação do cálculo o contingente de pessoas que assistem ao espetáculo (X6), pudemos obter:

$$
\mathrm{VAC}=\overline{\mathrm{X} 6} \times \overline{\mathrm{X} 4}
$$

Onde:

VAC $=$ Valor da Apresentação das Cavalhadas pelo MVC (primeira hipótese)

$\overline{\mathrm{X} 6}=$ Média de Público das Cavalhadas

$\overline{\mathrm{X}}$ = Média do Valor da Disposição a Pagar pelo ingresso diário

Na segunda situação hipotética, considerando o valor que estariam dispostos a pagar (DAP) para a manutenção da Festa (X5), e tomando-se como base para aplicação da fórmula um dado aproximado referente à população economicamente ativa (X2) do município de Pirenópolis (Censo 2000), teremos:

$$
\mathrm{VEF}(2)=\mathrm{X} 2 \times \overline{\mathrm{X} 5}
$$

Onde:

VEF(2) = Valor Econômico da Festa pelo MVC (segunda hipótese)

$\mathrm{X} 2$ = Estimativa da População ativa

$\overline{\mathrm{X} 5}=$ Média da Disposição a pagar por taxa para manutenção da festa 


\section{RESULTADOS E DISCUSSÕES}

$\mathrm{Na}$ análise dos resultados obtidos na consolidação das respostas, verificou-se no primeiro bloco de perguntas que apenas $32 \%$ dos entrevistados participaram da organização da Festa e 36\% conhecem sua origem e história. Apesar disso, para 93\% dessas pessoas a Festa tem grande representatividade.

Quando perguntados o que representaria para o município a não realização da festa, cerca de $93 \%$ dos entrevistados responderam que além da perda pelo aspecto da cultura e tradição, a cidade perderia com relação ao turismo, visto que conforme eles próprios afirmam, a divulgação da cidade pela Festa é de extrema importância para a manutenção e crescimento do turismo.

Identificou-se que a participação dos mesmos na Festa está basicamente ligada à colaboração através da doação de mercadorias e mão de obra. Conhecem em geral um mínimo sobre a origem da Festa e em sua maioria a vêem como um folclore, uma tradição popular. Apenas dois dos entrevistados responderam não demonstrarem sentimento algum pela realização da Festa, não tendo nenhuma forma de representação em suas vidas.

$\mathrm{Na}$ análise do segundo bloco de perguntas, do total dos entrevistados $82 \%$ responderam que a Festa trouxe mudanças positivas para o turismo local e 46,5\% acham que provocaram alguma mudança negativa.

Com relação ao terceiro e último bloco, quando perguntados sobre os benefícios trazidos pela Festa, são unânimes em dizer que a mesma traz benefícios para a cidade e que o maior deles é a divulgação por intermédio das Cavalhadas, e que apesar do período da Festa movimentar economicamente o município menos que outras datas como semana santa, carnaval, férias e outros feriados nacionais, a mídia gerada pela Festa promove um aumento do turismo local durante todo o ano.

Na opinião da maioria dos comerciantes entrevistados, os comércios mais beneficiados no período da Festa são bares, lanchonetes, algumas pousadas e restaurantes e barraqueiros e ambulantes (pessoas de fora). 
Apesar de haver variação nas opiniões a respeito da quantidade de turistas na cidade no período das Cavalhadas, a média ficou em torno de 8.200 pessoas, enquanto o número de turistas que assistem ao espetáculo no campo das Cavalhadas, a média ficou em torno de 6.400 pessoas.

É evidente o desconhecimento por parte dos entrevistados quanto aos investimentos públicos e privados na Festa, seja com relação a quem ou quanto é investido.

No que diz respeito ao valor gasto por dia por turista, com despesas de alimentação, transporte, hospedagem, entre outras, a média dos questionários aplicados apresentou um valor em torno de $\mathrm{R} \$ 134,00$.

Incitados a responder quanto valeria um ingresso para assistir às Cavalhadas e quanto estariam dispostos a dar de contribuição para evitar a extinção da mesma, na média obtivemos como resposta $\mathrm{R} \$ 4,00$ e $\mathrm{R} \$ 91,00$ respectivamente.

Para cálculo da população economicamente ativa do município de Pirenópolis, foram utilizados dados disponíveis no site do IBGE com relação à população de homens e de mulheres do município em 2000 e as respectivas taxas de atividade para pessoas de 15 a 65 anos na região centro-oeste no mesmo período. Como resultado obteve-se um número aproximado de 15.700 habitantes economicamente ativos em 2000.

Com base nos valores obtidos na pesquisa, podemos aplicar as fórmulas abaixo:

\section{$\mathrm{VEF} 1 \mathrm{1}=\overline{\mathrm{X} 1} \times \overline{\mathrm{X} 3}$}

Onde:

VEF(1) = Valor Econômico da Festa pelo MCV

$\overline{\mathrm{X} 1}=$ Média da População flutuante no fim de semana

$\overline{\mathrm{X} 3}=$ Média do Valor gasto por pessoa no fim de semana

Aplicando-se a fórmula proposta, e considerando os valores para:

$\overline{\mathrm{X} 1}=8.200$

$\overline{\mathrm{X} 3}=\mathrm{R} \$ 268,00$ (considerando o custo médio diário de $\mathrm{R} \$ 134,00$ por pessoa) 
Teremos:

$\mathrm{VEF}(1)=8.200 \times \mathrm{R} \$ 268,00$

$\mathrm{VEF}(1)=\mathrm{R} \$ 2.164 .800,00$

$\mathrm{OU}$

$\mathrm{VEF}(2)=\mathrm{X} 2 \times \overline{\mathrm{X} 5}$

Onde:

VEF(2)= Valor Econômico da Festa pelo MVC

X2 = Estimativa da População ativa

$\overline{\mathrm{X} 5}=$ Média da Disposição a pagar por taxa para manutenção da festa

Aplicando-se a fórmula proposta, e considerando os valores para:

$$
\begin{aligned}
& X 2=13.500 \\
& \bar{X} 5=R \$ 91,00
\end{aligned}
$$

Teremos:

$\mathrm{VEF}(2)=15.700 \times \mathrm{R} \$ 91,00$

$\mathrm{VEF}(2)=\mathrm{R} \$ 1.428 .700,00$

\section{E AINDA}

\section{$\mathrm{VAC}=\overline{\mathrm{X} 6} \times \overline{\mathrm{X} 4}$}

Onde:

VAC $=$ Valor da Apresentação das Cavalhadas pelo MVC

$\overline{\mathrm{X} 6}=$ Média de Público das Cavalhadas

$\overline{\mathrm{X}}$ = Média do Valor da Disposição a Pagar pelo ingresso diário

Aplicando-se a fórmula proposta, e considerando os valores para: 


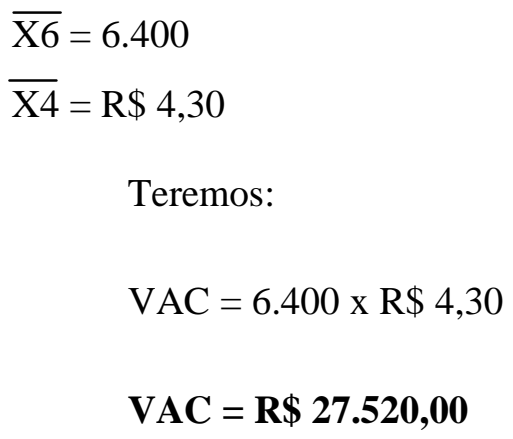

Ponto alto da Festa do Divino de Pirenópolis, as Cavalhadas atraem a população local, de cidades vizinhas, turistas nacionais e estrangeiros, estudiosos, historiadores, repórteres e autoridades em nível municipal, estadual e federal.

Em função disso, provoca grande visibilidade no Brasil e no exterior do município de Pirenópolis, muitas vezes citado como "a Cidade das Cavalhadas". A Festa é foco da mídia via televisão, rádio, internet, revistas, jornais e outros meios de comunicação. Sua realização, independente do investimento, transcende o poder público, estando alicerçada na manifestação popular. 


\section{CONCLUSÕES}

Com base nas análise realizadas conclui-se que:

- A população média flutuante no ápice da festa gira em torno de 8.200 pessoas.

- O contingente de pessoas que assistem ao espetáculo das Cavalhadas é em média de 6.400 pessoas.

- A população economicamente ativa no ano de 2.000 era de aproximadamente 15.700 pessoas.

- O gasto médio diário por pessoa durante o período foco da pesquisa, é de R $\$$ 134,00 (cento e trinta e quatro reais), incluindo transporte, hospedagem, alimentação, bebidas e outras compras ou despesas.

- A média do valor da Disposição a Pagar - DAP - por ingresso para assistir ao espetáculo das Cavalhadas, é de $\mathrm{R} \$ 4,00$ (quatro reais).

- A média do valor da Disposição a Pagar - DAP - por taxa para manutenção da festa, é de $\mathrm{R} \$ 91,00$ (noventa e um reais).

Aplicando-se os métodos de valoração escolhidos chegou-se aos seguintes valores:

Valor Econômico da Festa do Divino Espírito Santo em Pirenópolis pelo Método do Custo de Viagem:

- $\mathrm{R} \$ 2.164 .800,00$ (dois milhões, cento e sessenta e quatro mil e oitocentos reais).

Valor Econômico da Festa do Divino Espírito Santo em Pirenópolis pelo Método de Valoração Contingente:

- $\mathrm{R} \$ 1.428 .700,00$ (um milhão, duzentos e vinte e oito mil e quinhentos reais) considerando a Disposição a Pagar - DAP - dos membros da comunidade para manutenção da festa. 


\section{Valor da Apresentação das Cavalhadas pelo Método de Valoração Contingente:}

- $\mathrm{R} \$ 27.520,00$ (vinte e sete mil, quinhentos e vinte reais) - considerando a Disposição a Pagar - DAP - por ingresso para assistir ao espetáculo das Cavalhadas.

Algumas recomendações se fazem necessárias para outros estudos:

- Utilização de técnicas de amostragem probabilísticas que possibilitem inferir a respeito dos resultados da pesquisa de campo como sendo a opinião da comunidade;

- Aplicação de pesquisa (aplicação de questionários ou outra técnica), no período de realização da festa do Divino Espírito Santo de Pirenópolis;

- Os resultados deste trabalho não devem ser transportados e utilizados em outro bem cultural sem que seja efetuado novo estudo específico considerando as especificidades do novo tema;

- O fato de buscar traduzir economicamente uma festa cujo valor cultural não tem preço para uma população que se envolve, se dá, se integra e renasce com ela e seus elementos religiosos e profanos, não tenta induzir à capitalização da festa, mas apenas dar-lhe um valor que possa ser usado como indutor de investimentos públicos e privados na melhoria de sua infra-estrutura e na reparação de eventuais danos culturais pela descaracterização ou outros possíveis aspectos que possam trazer prejuízos para a cultura local. 


\section{ANEXO - QUESTIONÁRIO APLICADO}

\section{NOME:}

PROFISSÃO/ATIVIDADE:

1. Você já participou da organização da Festa do Divino Espírito Santo? Como? Quantas vezes?

2. Para você o que a Festa representa?

3. Você sabe como a Festa se originou? Explique.

4. Quais benefícios a Festa traz para Pirenópolis?

$\begin{array}{ll}\text { ( ) Renda } & \text { Quanto? } \\ \text { ( ) Emprego } & \text { De que forma? } \\ \text { ( ) Propaganda } & \text { De que tipo? } \\ \text { ( ) Impostos } & \text { Quais? } \\ \text { ( ) Reconhecimento } & \text { De que forma? } \\ \text { ( ) Valorização Cultural } & \text { Como? }\end{array}$

5. Considerando que a população de Pirenópolis é de 20 mil habitantes, em quanto ela é aumentada no período da Festa (principalmente nas Cavalhadas)?

( ) De 1.000 a 5.000 turistas

( ) De 5.000 a 10.000 turistas

( ) De 10.000 a 15.000 turistas

( ) Mais de 15.000 turistas

6. Quantas pessoas assistem a apresentação das Cavalhadas?
( ) De 100 a 500 pessoas
( ) De 500 a 1.000 pessoas
( ) De 1.000 a 2.000 pessoas
( ) De 2.000 a 5.000 pessoas
( ) Mais de 5.000 pessoas

Quantas?

7. Qual o tipo de comércio que mais se beneficia com a Festa?

( ) Hotéis/pousadas

( ) Restaurantes

( ) Bares e lanchonetes

( ) Lojas de artesanato

( ) Postos de combustível

( ) Supermercados

( ) Comércio de roupas

( ) Outros

8. Qual o gasto individual do turista por dia na época da Festa?

( ) De $R \$ 10,00$ a $R \$ 20,00$

( ) De $R \$ 20,00$ a $R \$ 40,00$

( ) De $\mathrm{R} \$ 40,00$ a $\mathrm{R} \$ 100,00$

( ) De $R \$ 100,00$ a $R \$ 200,00$

( ) Mais de $R \$ 200,00$

9. Durante as festividades das Cavalhadas o seu comércio fatura mais? Quanto em média?

10. Há outras épocas melhores de faturamento do que as Cavalhadas? Quais? ( ) Carnaval 


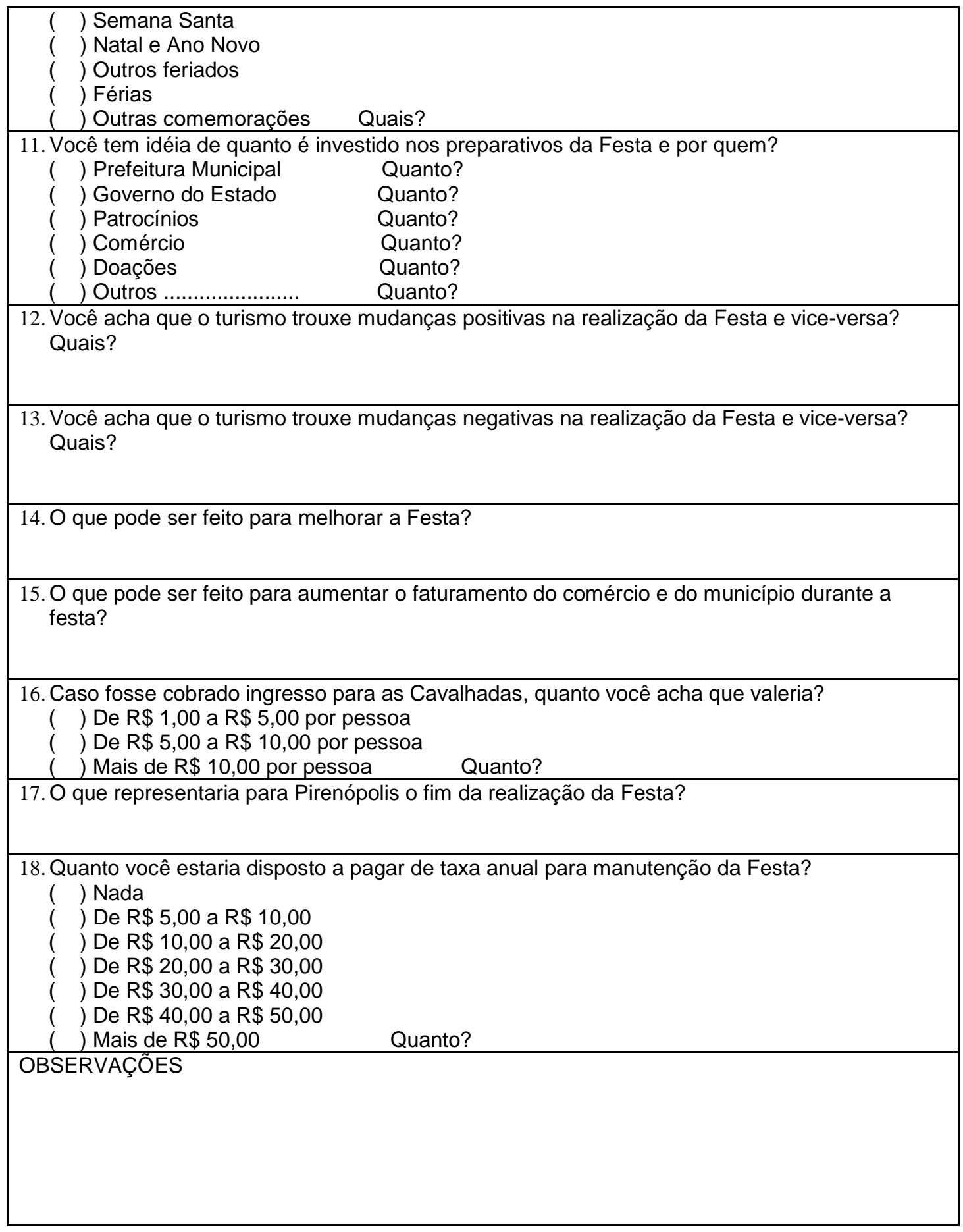




\section{REFERÊNCIAS BIBLIOGRÁFICAS}

AGETUR, Agência Goiana de Turismo.<www.agetur.go.org.br >, acessado em 24 mar 2003.

FALCÃO, Joaquim. Patrimônio Imaterial: Um sistema sustentável de proteção. Revista Tempo Brasileiro. Rio de Janeiro: Ed. Tempo Brasileiro, out-dez, nº 147, p.163, 2001.

FENNELL, David A. Ecoturismo. São Paulo: Contexto, 2002.

FERREIRA, Aurélio Buarque de Holanda. Minidicionário da língua portuguesa/Aurélio Buarque de Holanda Ferreira; coordenação Marina Baird Ferreira, Margarida dos Anjos; equipe Elza Tavares Ferreira. $3^{\text {a }}$ edição. Rio de Janeiro: Nova Fronteira, 1993.

IBGE, Instituto Brasileiro de Geografia e Estatística. < www.ibge.org.br >, acessado em 24 mar 2003.

INSTITUTO DO PATRIMÔNIO HISTÓRICO E ARTÍSTICO NACIONAL. Patrimônio Imaterial: $O$ Registro do Patrimônio Imaterial: Dossiê final das atividades da Comissão e do Grupo de Trabalho Patrimônio Imaterial. Brasília:, 2000.

MARCONI, Marina de Andrade \& LAKATOS, Eva Maria. Técnicas de Pesquisa: planejamento e execução de pesquisas, amostragens e técnicas de pesquisa, elaboração, análise e interpretação de dados. $1^{\text {a }}$ edição. São Paulo, 1982.

LINDBERG, Kreg \& HAWKINS, Donald E.(Editores). Ecoturismo: Um guia para planejamento e gestão. $3^{\text {a }}$. edição. Tradução de Leila Cristina M. Darin. São Paulo: Editora SENAC São Paulo, 2001.

MOTTA. R. S. Manual para valoração econômica de recursos ambientais. Brasília: MMA. 1998a. 218p. 
MURTA, Stela Maris, ALBANO, Celina (orgs.). Interpretar o Patrimônio: Um exercício do olhar. Belo Horizonte: Ed UFMG, Território Brasilis, 2002.

NIEFER, I. \& SILVA, J. C. L. G. da. Critérios para um ecoturismo ambientalmente saudável. Cadernos da Biodiversidade, V.2, n.1, jul.1999, p.53-61,1999.

SANT’ANNA, Márcia. Patrimônio Imaterial: Um Sistema Sustentável de Proteção. Revista Tempo Brasileiro. Rio de Janeiro: Ed. Tempo Brasileiro, out-dez., nº 147, p.151-161, 2001 .

SANTOS, Angelo Oswaldo de Araújo Santos. Desmaterialização do Patrimônio. Revista Tempo Brasileiro. Rio de Janeiro: Ed. Tempo Brasileiro, out-dez., n ${ }^{\circ}$ 147, p.11-21, 2001.

SILVA, Luciana Ferreira da. Valoração Econômica de Áreas de Recreação: Instrumento de Gestão para o Balneário Municipal de Bonito - Mato Grosso do Sul. Brasília, 2001. (Dissertação - Mestrado em Gestão Ambiental e Políticas Públicas - Universidade de Brasília, Centro de Desenvolvimento Sustentável.)

SILVA, Mônica Martins da. A Festa do Divino: romanização, patrimônio \& tradição em Pirenópolis (1890-1988). Mônica Martins Silva. Goiânia, 2001.

VEIGA, Felipe Berocan. A Festa do Divino Espírito Santo em Pirenópolis - Polaridades simbólicas em torno de um rito. Niterói: 2002. 210p. Dissertação (mestrado). Programa de Pós-graduação em Antropologia e Ciência Política - UFF (mimeogr.). 